\title{
Panic disorder as presenting symptoms of multiple sclerosis
}

\author{
Demet İlhan Algin ${ }^{1 *}$, Alev Kilicoglu², Mustafa Koplay ${ }^{3}$ \\ From $1^{\text {st }}$ International Congress on Neurobiology and Clinical Psychopharmacology and European \\ Psychiatric Association Conference on Treatment Guidance \\ Thessaloniki, Greece. 19-22 November 2009
}

\section{Background}

Multiple sclerosis (MS) is a chronic demyelinating disorder characterized by multiple neuropsychiatric symptoms Psychiatric disorders and symptoms may accompany the course of MS as primary or secondary reasons $[1,2]$. We will present a case report with panic disorder as presenting symptoms of multiple sclerosis.

\section{Materials and methods}

A 47 years old female patient admitted to psychiatry clinic with attacs of palpitation, sweating, dispnea with a feeling of heart attack. These symptoms were present for 3 months,3-4 times a week and the patient started to have expectation anxiety. She was diagnosed as panic disorder and started paroxetine $20 \mathrm{mg} / \mathrm{day}$. After one month her symptoms were not beter, and because of reference delusions as if people were looking at her, olanzapine $10 \mathrm{mg} /$ day was added. After another month of medication, because she was not better, she was sent to neurology and she had a cerebral magnetic resonance imaging(MRI).In her neurologic examination her deep tendon reflexes were found to be increased. In her MRI a right frontal $10 \times 5 \mathrm{~mm}$ periventricular deep white matter plaque and multiple subcorticle white matter hyperintense plaques were seen. In her serebrospinal oligoclonal band was positive. She was diagnosed as multiple sclerosis and after 5 day treatment of methylprednisolone $1000 \mathrm{mg} /$ day, her psychiatric symptoms disappeared.

\section{Results}

Psychiatric symptoms may be primary symptoms of a new demyelinization epizode.

'Department of Neurology, Dumlupinar University, Kutahya, Turkey

\section{Conclusions}

A MS patient may admit with psychiatric symptoms and there may be a misdiagnosis of psychiatric disorder.

\section{Author details}

'Department of Neurology, Dumlupinar University, Kutahya, Turkey.

${ }^{2}$ Department of Psychiatry, Dumlupinar University, Kutahya, Turkey.

${ }^{3}$ Department of Radiology, Dumlupinar University, Kutahya, Turkey.

Published: 22 April 2010

References

1. Korostil M, Feinstein A: Anxiety disorders and their clinical correlates in multiple sclerosis patients. Mult Scler 2007, 13(1):67-72.

2. Minden SL: Mood disorders in multiple sclerosis: diagnosis and treatment. J Neurovirol. 2000, 6(Suppl 2):S160-7.

doi:10.1186/1744-859X-9-S1-S138

Cite this article as: Algin et al:: Panic disorder as presenting symptoms of multiple sclerosis. Annals of General Psychiatry 2010 9(Suppl 1):S138.

Submit your next manuscript to BioMed Central and take full advantage of:

- Convenient online submission

- Thorough peer review

- No space constraints or color figure charges

- Immediate publication on acceptance

- Inclusion in PubMed, CAS, Scopus and Google Scholar

- Research which is freely available for redistribution 